\title{
AGE-DEPENDENT CHANGES IN PLASMA AMINO ACIDS CONTRIBUTE TO ALTERATIONS IN GLYCOXIDATION PRODUCTS
}

\author{
PROMENE AMINO KISELINA U PLAZMI POVEZANE SA STAROŠĆU DOPRINOSE \\ ALTERACIJAMA U PRODUKTIMA GLIKOKSIDACIJE
}

\author{
Elaheh Foroumandi ${ }^{1}$, Mohammad Alizadeh ${ }^{2}$, Sorayya Kheirouri ${ }^{3}$ \\ ${ }^{1}$ Department of Nutrition, Faculty of Nutrition, Tabriz University of Medical Sciences, Tabriz, Iran \\ ${ }^{2}$ Nutrition Research Center, Tabriz University of Medical Sciences, Golgasht St, Tabriz, Iran \\ ${ }^{3}$ Department of Nutrition, Faculty of Nutrition, Tabriz University of Medical Sciences, Tabriz, Iran
}

\begin{abstract}
Summary
Background: Glycative stress is involved in the pathogenesis of various degenerative disorders. This study sought to determine the effect of age-related changes in amino acids on serum levels of pentosidine and carboxymethyl-lysine $(\mathrm{CML})$ in healthy individuals.

Methods: The subjects were 78 healthy individuals categorized into three age groups. The ages of the groups were as follows: 26 young adults (20-30 y, 25.2 \pm 3.03$), 26$ middle-aged adults (35-50 y, 39.46 26.97$)$ and 26 older adults (60 y or older, 69.80 \pm 10.01 ). Serum levels of pentosidine and CML were measured by ELISA and levels of plasma amino acids were determined using HPLC.

Results: Serum levels of pentosidine and CML in the youngest group were higher than in the oldest group $(p=0.026$, 0.029 , respectively). There was a positive correlation between the serum levels of pentosidine and CML and the levels of plasma Tyrosine $(p=0.032, r=0.211$ and $p=0.037, r=0.224)$, Valine $(p=0.037, r=0.224$ and $p=0.021, r=0.247)$ and Isoleucine ( $p=0.041, r=0.203$ and $p=0.021, r=0.247)$, respectively. Serum levels of pentosidine and CML may be modulated by the plasma levels of selected amino acids.

Conclusions: Better understanding of the role of these selective amino acids might provide new perception of how glycation pathways may be altered and pave the way for new therapeutic principles.
\end{abstract}

Keywords: advanced glycation end product, amino acid, aging, glycation, healthy

\section{Kratak sadržaj}

Uvod: Stres izazvan glikacijom učestvuje u patogenezi raznih degenerativnih bolesti. $U$ ovoj studiji namera je bila da se utvrdi uticaj promena u amino kiselinama koje su povezane sa starošću na serumske nivoe pentozidina i karboksimetillizina (CML) kod zdravih osoba.

Metode: Ispitanike je činilo 78 zdravih osoba podeljenih prema starosti u tri kategorije. Starosne grupe su izgledale ovako: 26 mladih odraslih osoba (20-30 god, 25,2 $\pm 3,03)$, 26 sredovečnih osoba $(35-50$ god, $39,46 \pm 6,97)$ i 26 starijih osoba (60 god. i više, $69,80 \pm 10,01$ ). Nivoi pentozidina i CML u serumu mereni su tehnikom ELISA a nivoi amino kiselina u plazmi određeni su metodom HPLC.

Rezultati: Nivoi pentozidina i CML u serumu u najmlađoj grupi bili su viši nego u najstarijoj grupi ( $p=0,026$, odnosno 0,029 ). Postojala je pozitivna korelacija između serumskih nivoa pentozidina i CML i nivoa tirozina $(p=0,032, r=0,211$ i $p=0,037, r=0,224)$, valina $(p=0,037, r=0,224$ i $p=0,021$, $r=0,247)$ i izoleucina $(p=0,041, r=0,203$ i $p=0,021$, $r=0,247$ ) u plazmi. Serumski nivoi pentozidina i CML možda modulišu nivoe izabranih amino kiselina u plazmi.

Zaključak: Bolje razumevanje uloge ovih izabranih amino kiselina može omogućiti novo shvatanje toga kako se mogu menjati putevi glikacije i otvoriti prostor za nove terapijske principe.

Ključne reči: krajnji produkt uznapredovale glikacije, amino kiselina, starenje, glikacija, zdrav

Address for correspondence:

Mohammad Alizadeh

Nutrition Research Center,

Tabriz University of Medical Sciences,

Golgasht St, Tabriz, Iran

Tel: +984133376228 Fax: +984133340634

e-mail: mdalizadeh@tbzmed.ac.ir 


\section{Introduction}

Aging is an inevitable complex reality that happens to every living organism (1). There are more than 300 theories of aging (2). Over the years, gerontologists have found that aging has no universal cause, phenotype or consequences (3). Aging is a multifactorial process in which genetic, endogenous and environmental factors play a role (4) and is frequently characterized by accumulated damage at the molecular, cellular and organ levels which results in many functional deficits in different body organs, including musculoskeletal, vascular, neural, and endocrine systems (5).

Muscle wasting is an important life-long process with a complex and multifactorial etiology (6). An imbalance between the rate of protein synthesis and protein breakdown can lead to the loss of muscle proteins. The mechanisms involved in this action are not clearly understood (7). Amino acid transportation to the muscular cells is a major determinant in the regulation of protein anabolism $(8,9)$. The availability of blood amino acids is a potent stimulus for muscle protein synthesis $(6,10)$. Non-enzymatic modification of ketones or aldehydes and the free amino groups of various proteins lead to the formation of advanced glycation end products (AGEs) $(11,12)$. AGEs are a group of complex and heterogeneous compounds (13) and accumulation of these products may be amplified by a continuing cycle of metabolic stress, tissue damage, and cell death leading to increased free radical production (14). Recent epidemiological studies demonstrate that elevated circulating AGEs are linked to chronic disease processes through the induction of inflammatory reactions $(15,16)$. The symptoms of Alzheimer's disease, such as neuronal cell death, amyloid plaque formation, and neuronal tangles may therefore be caused by the glycation of proteins (17).

It has been shown that the amount of AGEs is dependent on the inherent reactivity of specific amino groups, as determined by the glucose concentration and the half-life of the protein (18). We speculated that plasma amino acids can affect serum AGEs, due to alterations in plasma amino acids during the aging process.

Many previous studies have pointed to an increase in the accumulation of AGEs with aging. However, most of these studies have been limited to measuring the amount of AGEs correlated to chronological aging, and did not measure the formation of AGEs with regards to the quantity of their precursors such as amino acids. Since many of these processes in the body are not just dependent on chronological aging, the aim of our study was to (1) determine the agerelated alterations of plasma amino acids and serum AGEs and (2) investigate whether any correlation exists between levels of specific amino acids and the formation of AGEs with regards to different age groups.

\section{Materials and Methods}

\section{Sampling method}

This cross-sectional study was conducted from January to March 2016. A total of 78 healthy subjects in three age groups were recruited by convenience sampling from the people who attended the public health centers and old people's homes affiliated to Tabriz University of Medical Sciences, Tabriz, Iran. Members of three different age groups were randomly selected in this study as follows: 26 young adults (20-30 years), 26 middle-aged adults (35-50 years) and 26 older adults (over 60 years). All of the participants provided written informed consent to participate in the trial. The protocol was approved by the ethical committee of the Tabriz University of Medical Sciences, Tabriz, Iran (reference number: TBZMED.REC.1394.1032). The exclusion criteria were as follows: those suffering from any disease including chronic diseases and mental illness, regular drug therapy, a history of smoking or a history of alcohol consumption. Each group included an equal number of males and females.

Collection of basic characteristics and anthropometric indices

Body weight was determined to the nearest $0.1 \mathrm{~kg}$ on an electronic digital scale while the subjects were wearing light clothing, and height was measured to the nearest $0.1 \mathrm{~cm}$. Body mass index $(\mathrm{BMI})$, defined as the weight in kilograms of the individual divided by the square of the height in meters was then calculated. Waist circumference (WC) was measured as the minimum circumference between the iliac crest and the rib cage. Hip circumference was measured at the maximum protuberance of the buttocks, and the waist-to-hip ratio (WHR) defined as WC $(\mathrm{cm})$ divided by hip circumference $(\mathrm{cm})$.

\section{Blood chemistry}

Blood samples were taken in the morning after 12-14 $\mathrm{h}$ fasting from the antecubital fossa and divided into two different glass tubes; one was heparinized containing $5.9 \mathrm{mg} \mathrm{K} \mathrm{K}_{2}$ EDTA for amino acid measurement and another with a clot activator and gel separator for the measurement of AGEs. The serum and plasma samples were centrifuged for $10 \mathrm{~min}$ at 300 $\mathrm{g}$ and were then frozen at $-20{ }^{\circ} \mathrm{C}$ until being thawed for analysis.

\section{Determination of amino acids}

Plasma amino acids levels were determined by an HPLC (High-performance Liquid Chromatography) method (KNAUER, Germany), coupled with a fluorescence detector set at excitation/emission of 280/320 
nm (KNAUER, Germany). A gradient mobile phase of sodium acetate $(0.1 \mathrm{~mol} / \mathrm{L} \mathrm{pH} 7.2)$ and methanol with $70: 30 \% \mathrm{v} / \mathrm{v}$ was used to separate the compounds on inertsil ODS-2 C18 (250 $\mathrm{mm} \times 4 \mathrm{~mm}$ ID, $5 \mu \mathrm{m}$ particle size) column. The column temperature was maintained at $40{ }^{\circ} \mathrm{C}$. For internal standardization, homoserine powder was mixed in methanol and added to $200 \mu \mathrm{L}$ of the prepared sample and $800 \mu \mathrm{L}$ methanol. The pre-column derivatization was conducted by addition of $50 \mu \mathrm{L}$ O-phthaldialdehyde (OPA), $100 \mu \mathrm{L}$ borate and $25 \mu \mathrm{L}$ HCL. Then, $50 \mu \mathrm{L}$ of the prepared liquid was added to the mobile phase, and finally an amount of $40 \mu \mathrm{L}$ was injected into the HPLC system. Flow rate was set at $1 \mathrm{~mL} / \mathrm{min}$.

\section{Determination of advanced glycation end products}

Commercially available kits were used to determine the levels of serum pentosidine or CML (Cat. No. E0004Hu and E1413Hu; Bioassay Technology Laboratory, Shanghai, China, respectively) following the manufacturers' instructions. Briefly, the standards and samples were pipetted into the 96-well pre-coated microplate with an antibody specific for pentosidine or $\mathrm{CML}$, and then incubated at $37^{\circ} \mathrm{C}$. After five washes, avidin conjugated horseradish peroxidase was added to the wells and incubated for 15-25 minutes at $37{ }^{\circ} \mathrm{C}$. Finally, the reaction was stopped and the optical density was measured at $450 \mathrm{~nm}$ with an ELISA reader.

\section{Statistics}

Amino acid and AGEs concentrations in the three age groups were compared by one-way analysis of variance (ANOVA) followed by the Tukey's HSD post hoc test. The partial correlation analysis was applied to determine the correlations between amino acids and AGEs. The independent sample $t$ test was performed to compare the means of serum AGEs concentrations in each sex group. A $P$ value $<0.05$ was considered significant. All of the data were checked for distribution using the KolmogorovSmirnov test. Analyses were performed using SPSS software, version 23.0 (SPSS, Chicago, Illinois, USA).

\section{Results}

A total of 78 subjects were included in this study. Demographic and clinical characteristics are presented in Table I. The average age of the young, middle and oldest subjects was 25.2 $\pm 3.0,39.4 \pm 6.9$ and $69.8 \pm 10.0$ years, respectively. These data indicated that the three study groups did not differ with regards to BMI. The mean body weight was $66.88 \pm 9.64 \mathrm{~kg}$, $72.95 \pm 12.60 \mathrm{~kg}$ and $64.11 \pm 19.26 \mathrm{~kg}$ in each study group, respectively. The younger group had a significantly higher WHR compared to either the middleaged or oldest groups ( $p=0.039,0.008$ respectively). The dietary intake and physical activity of the subjects were assessed and found not to differ significantly between the study groups (data not shown).

Table /l shows the normal reference ranges for concentrations of amino acids in the plasma. All of the measured amino acids concentrations were within their reference ranges, except for Arg which was higher than normal range in all three study groups and Met which was lower than normal range in all of the study groups. Asn and Ala were only higher than normal range in the oldest group and Leu was lower in the oldest group. Glu was higher than normal range in the middle group. Alterations in the plasma levels of Asp, Asn, Gly, Thr, Lys, Val, Leu and Ileu were also seen with aging.

Figure 1 shows the levels of serum pentosidine and $C M L$ in the three age groups. The concentration of pentosidine was $3.71 \pm 0.63(\mathrm{ng} / \mathrm{mL})$ in the young group, $3.49 \pm 0.57$ in the middle group and $3.22 \pm$

Table I Clinical characteristics of subjects (mean \pm SD).

\begin{tabular}{|c|c|c|c|c|}
\hline & \multicolumn{3}{|c|}{ Group } & P. value $e^{* *}$ \\
\hline & Young $(n=26)$ & Middle $(n=26)$ & Old $(n=26)$ & \\
\hline Age (years) & $25.20 \pm 3.03^{a}$ & $39.46 \pm 6.97^{b}$ & $69.80 \pm 10.01^{c}$ & $<0.001$ \\
\hline Body weight $(\mathrm{kg})$ & $66.88 \pm 9.64$ & $72.95 \pm 12.60$ & $64.11 \pm 19.26$ & 0.058 \\
\hline Height (cm) & $168.18 \pm 9.22^{a}$ & $165.66 \pm 10.37^{a b}$ & $161.51 \pm 10.98^{b c}$ & 0.043 \\
\hline $\mathrm{BMI}^{*}$ & $23.75 \pm 3.64$ & $26.57 \pm 3.64$ & $24.37 \pm 6.40$ & 0.059 \\
\hline $\mathrm{WHR} * *$ & $0.85 \pm 0.07^{a}$ & $0.90 \pm 0.09^{a b}$ & $0.95 \pm 0.07^{b c}$ & 0.008 \\
\hline
\end{tabular}

*Body mass index $=$ weight $(\mathrm{kg}) /$ height $\left(\mathrm{m}^{2}\right) .{ }^{* *}$ Waist to hip ratio=waist circumference $(\mathrm{cm}) /$ hip circumference $(\mathrm{cm}){ }^{* * *}$ Based on one-way ANOVA 
Table II Plasma concentration of amino acids (mean \pm SEM).

\begin{tabular}{|c|c|c|c|c|c|}
\hline & Young $(n=26)$ & Middle $(n=26)$ & Old $(n=26)$ & p.value* & Normal Range \\
\hline Asp & $17.74 \pm 1.55^{a}$ & $12.60 \pm 1.22^{b}$ & $12.87 \pm 1.39^{b c}$ & 0.017 & $2-25$ \\
\hline Glu & $230.07 \pm 27.11$ & $257.90 \pm 29.55$ & $230.54 \pm 19.13$ & 0.681 & $26-240$ \\
\hline Asn & $64.96 \pm 6.11^{a}$ & $74.29 \pm 7.15^{a b}$ & $105.12 \pm 14.08^{b c}$ & 0.012 & $20-80$ \\
\hline Ser & $144.16 \pm 13.02$ & $109.05 \pm 12.56$ & $133.48 \pm 12.36$ & 0.538 & $80-230$ \\
\hline His & $74.24 \pm 6.48$ & $75.56 \pm 8.31$ & $81.70 \pm 8.02$ & 0.764 & 54-120 \\
\hline Gly & $163.21 \pm 11.32^{a}$ & $170.27 \pm 13.18^{a b}$ & $238.88 \pm 12.52^{c}$ & $<0.001$ & $135-350$ \\
\hline Thr & $106.52 \pm 8.47^{a}$ & $101.35 \pm 9.03^{a b}$ & $82.09 \pm 8.10^{C}$ & 0.001 & $60-205$ \\
\hline Cit & $27.19 \pm 1.58^{a}$ & $26.23 \pm 2.26^{a b}$ & $32.53 \pm 1.94^{c}$ & 0.054 & $10-45$ \\
\hline Arg & $42.24 \pm 5.37$ & $43.03 \pm 5.49$ & $43.61 \pm 3.57$ & 0.981 & $12-40$ \\
\hline Ala & $287.51 \pm 24.19$ & $294.25 \pm 25.22$ & $336.38 \pm 27.50$ & 0.350 & $123-310$ \\
\hline Tyr & $62.80 \pm 7.37$ & $59.30 \pm 5.51$ & $53.39 \pm 4.72$ & 0.534 & $32-85$ \\
\hline Met & $13.63 \pm 1.79$ & $15.04 \pm 2.79$ & $16.75 \pm 2.41$ & 0.650 & $28-110$ \\
\hline Val & $151.41 \pm 13.48^{a}$ & $142.33 \pm 14.76^{a b}$ & $106.64 \pm 10.79^{c}$ & 0.043 & 60-190 \\
\hline Phe & $33.75 \pm 3.31^{a}$ & $32.400 \pm 3.41^{a b}$ & $43.50 \pm 3.60^{c}$ & 0.051 & $32-85$ \\
\hline Ileu & $47.84 \pm 4.06^{a}$ & $43.98 \pm 3.92^{a b}$ & $33.13 \pm 3.55^{b c}$ & 0.024 & $28-110$ \\
\hline Leu & $79.52 \pm 6.64^{a}$ & $72.87 \pm 6.96^{a}$ & $52.49 \pm 6.18^{b c}$ & 0.013 & $60-190$ \\
\hline Orn & $76.42 \pm 6.85$ & $78.93 \pm 8.10$ & $93.19 \pm 7.65$ & 0.244 & $28-110$ \\
\hline Lys & $104.64 \pm 8.00^{a}$ & $104.36 \pm 10.50^{a b}$ & $143.90 \pm 11.84^{c}$ & 0.009 & $80-240$ \\
\hline
\end{tabular}

*Based on Post Hoc, Tukey Test

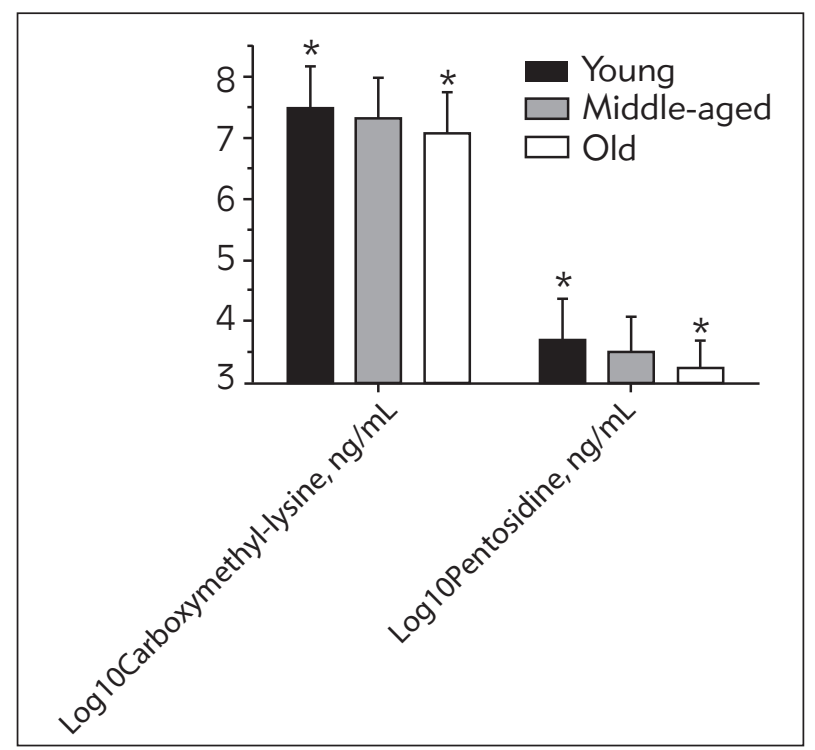

Figure 1 Serum carboxymethyl-lysine and pentosidine levels in study groups by age. ${ }^{*} \mathrm{p}<0.05$. $0.53(\mathrm{ng} / \mathrm{mL})$ in the oldest group $(p=0.026)$. Levels of CML were $7.52 \pm 0.69$ and $7.32 \pm 0.65(\mathrm{ng} / \mathrm{mL})$ in the young and middle-aged groups respectively and decreased to $7.12 \pm 0.61(\mathrm{ng} / \mathrm{mL})$ in the oldest group $(p=0.029)$.

Table III presents the correlations among CML or pentosidine and amino acids using the partial correlation test after adjustment for sex, BMI and WHR. Serum pentosidine was significantly correlated with levels of plasma Tyr $(r=0.211, p<0.05)$, Val $(r=0.224, p<0.05)$ and Ileu $(r=0.203, p<0.05)$. We also found correlations between $\mathrm{CML}$ and $\mathrm{Tyr}$ $(r=0.224, p<0.05)$, Val $(r=0.247, p<0.05)$ and Ileu $(r=0.247, p<0.05)$. These two AGEs had no significant correlations with the other amino acids that were measured in this study.

Table IV shows the concentrations of AGEs in different sex groups. Serum pentosidine and CML were higher in female than in male individuals $(p=$ 0.046 and 0.049 respectively). 
Table III Correlations among carboxymethyl-lysine, pentosidine and amino acids.

\begin{tabular}{|c|c|c|c|c|}
\hline & \multicolumn{2}{|c|}{ Log10Carboxymethyl-lysine* } & \multicolumn{2}{l|}{ Log10Pentosidine* } \\
\hline & $\mathrm{R}$ & $\mathrm{P}$ & $\mathrm{R}$ & $\mathrm{P}$ \\
\hline Asp & 0.022 & 0.837 & 0.018 & 0.870 \\
\hline Glu & 0.191 & 0.076 & 0.147 & 0.174 \\
\hline Asn & 0.135 & 0.212 & 0.119 & 0.272 \\
\hline Ser & -0.057 & 0.599 & -0.079 & 0.469 \\
\hline His & -0.033 & 0.758 & -0.038 & 0.726 \\
\hline Gly & -0.163 & 0.132 & -0.143 & 0.187 \\
\hline Thr & -0.005 & 0.961 & 0.051 & 0.636 \\
\hline Cit & 0.071 & 0.515 & 0.036 & 0.739 \\
\hline Arg & 0.124 & 0.254 & 0.079 & 0.469 \\
\hline Ala & 0.122 & 0.260 & 0.146 & 0.178 \\
\hline Tyr & 0.224 & 0.037 & 0.211 & 0.032 \\
\hline Met & 0.049 & 0.651 & 0.057 & 0.598 \\
\hline Val & 0.247 & 0.021 & 0.224 & 0.037 \\
\hline Phe & 0.154 & 0.154 & 0.156 & 0.148 \\
\hline Ileu & 0.247 & 0.021 & 0.203 & 0.041 \\
\hline Leu & 0.156 & 0.150 & 0.089 & 0.412 \\
\hline Orn & 0.117 & 0.279 & 0.075 & 0.491 \\
\hline Lys & 0.140 & 0.197 & 0.127 & 0.243 \\
\hline
\end{tabular}

*Pearson analysis*

age, sex, BMI and WHR as covariates

Table IV Serum AGEs concentration based on sex groups (mean \pm SD).

\begin{tabular}{|l|c|c|c|}
\hline \multirow{2}{*}{ Variables } & \multicolumn{3}{|c|}{ Sex } \\
\cline { 2 - 4 } & $\begin{array}{c}\text { Men } \\
(\mathrm{n}=39)\end{array}$ & $\begin{array}{c}\text { Women } \\
(\mathrm{n}=39)\end{array}$ & P. value* \\
\hline $\begin{array}{l}\text { Carboxymethyl- } \\
\text { lysine (ng/mL) }\end{array}$ & $3.10 \pm 0.24$ & $3.23 \pm 0.29$ & 0.049 \\
\hline $\begin{array}{l}\text { Pentosidine } \\
\text { (ng/mL) }\end{array}$ & $1.43 \pm 0.22$ & $1.56 \pm 0.25$ & 0.046 \\
\hline
\end{tabular}

*Based on Independent samples T-test

\section{Discussion}

We demonstrated that concentrations of serum pentosidine and CML had positive correlations with levels of plasma Tyr, Val and lleu amino acids. It is known that amino acids heated in the presence of reducing sugars can produce AGEs. A decrease in glycated proteins and amino acids can lead to a reduction in AGEs. Since the accumulation of AGEs is involved in the pathogenesis of many age-related diseases, these findings may provide the basis for the application of appropriate dietary regimens and food supplements to improve health conditions in the elderly.

These observations on the correlation between levels of selected amino acids and specific AGEs have not been reported elsewhere. Exner et al. (19) reported that the production of p-hydroxyphenylacetaldehyde that causes CML accumulation is barely quantitative at physiological concentrations of tyrosine amino acid (19-21). Furthermore, Lyer et al. (22) have reported that supplementation with curry leaf powder induced a transient reduction in glycated proteins and amino acids by reducing the level of total amino acids (22). Overall, it appears that selected amino acids are involved in the specific modulation of glycation. Judging from the lower levels of three plasma amino acids (Tyr, Val, and lleu) and the concurrent reduction in serum AGEs levels, it is suggested that these selected amino acids are the main precursors in the formation of AGEs during aging. To the best of our knowledge, this is a new finding in the current literature.

We have also determined that the profile of plasma amino acids was affected by the age of the study participants. For instance, plasma Asp, Thr, Leu, llue and $\mathrm{Val}$ in middle and oldest groups were lower than in the young adults; and levels of Asn, Gly and Lys were higher in the young group as compared with the middle or oldest groups. It is known that health in the elderly could be affected by alteration in the levels of different amino acids. These alterations indicate differences in protein metabolism in the elderly. Indeed, alterations in amino acids during aging might be related to the age-related deterioration in liver function, since enzymes needed for protein metabolism in older individuals possess a lower catalytic ability compared to those of younger individuals (23). In line with our study, Yamamoto et al. (24) reported a correlation between age and plasma amino acid levels in 1890 Japanese individuals. They noticed that the highest plasma amino acid was Cit (24). De Alvaro et al. (25) found that BCAA concentrations reduced and Phe increased with aging. Lawton et al. (26) revealed that Cys, Gly and Pro levels were lower in young adults than in elderly individuals. Menni et al. (27) reported that Val, Met, lleu, Leu, Phe and Lys were lower in the older subjects than in younger adults. These observations could be explained in part by alterations in steroid hormones such as estrogens and 
androgens, as a reduction in the serum levels of these hormones has adverse effects on nitrogen retention which decreases the plasma levels of amino acids (28). Adequate dietary intake, metabolic rate and nutrient interaction within the gastrointestinal systems are also factors that influence plasma amino acid status (29). Thus, careful regulation of amino acid intake may result in a better plasma amino acid balance and in turn regulate many biogenic factors in protein synthesis.

We further compared serum pentosidine and CML between the sexes. We found that women had higher AGEs in comparison to men. This finding was consistent with previously published data. For instance, studies showed higher pentosidine in the serum, urine, skin and cartilage of women (30-32). Van Deemter et al. (33) revealed that pentosidine concentrations were higher in the vitreous base and posterior vitreous of the eyes in women. It can be hypothesized that the hormones involved in protein metabolism, the content of body water or content and distribution of body fat may influence AGE concentrations. Further studies should elucidate whether the accumulation of AGEs is directly related to decreased hormone levels.

In this study, the oldest group had significantly lower serum pentosidine and CML levels than the two younger groups. Our results are surprising, since it has generally been accepted that the formation of AGEs increases in an age-dependent manner. For example, Kandarakis et al. (34) reported that there was a linear age-dependent increase in pentosidine and CML concentrations on Bruch's membranes, choroidal extracellular matrix, and vessel walls. Other studies reported that serum, plasma and cortical bone pentosidine in healthy and non-diabetic subjects increased exponentially during aging by $200 \%$ (3537). Furthermore, Takahashi et al. (38) demonstrated that serum pentosidine was significantly higher in those over the age of 50 than in younger individuals, and that the value for the group aged 80-93 years was threefold that of the group aged 20-29 years. However, there are some contradictory findings too. Rattiste et al. (39) reported that skin pentosidine levels of male common gulls (Laruscanus), aging from 2 to 30 years, did not correlate with the chronological age of the birds. Hein et al. (40) also reported that levels of pentosidine and CML in patients classified into different osteoporosis scales had no correlations with the levels of AGEs or the age of the participants. Knecht et al. (41) revealed a decrease in urine fructoselysine (FL) concentrations with aging, which is the $\mathrm{CML}$ precursor. This study indicated that the CML to FL ratio had no correlation with age in either diabetic or control subjects. Serum AGEs are partly exogenously derived from some foods, in addition to their endogenous production by non-enzymatically glycated proteins. Intake of higher levels of animal-derived foods and high- and dry-heat processed foods may raise AGEs accumulation in the body (42). The fact that the majority of old subjects in the current study lived in old people's homes that received healthy packaged food daily as opposed to the young subjects who may have received a more unhealthy diet and fast food could be effective in the serum AGEs falling by aging. On the other hand, in line with our study, it seems that AGEs are not only related to changes in physiology, but are also influenced by the availability of specific amino acids (Tyr, Val, Ileu). Thus, regular monitoring of these amino acids and subsequent supplementation may help improve protein synthesis and decrease AGEs accumulation in the elderly.

\section{Conclusion}

In conclusion, there was a correlation between serum AGEs and plasma Tyr, Val and Ileu. Thus, better understanding of the role of these selective amino acids might provide new perception of how glycation pathways may be altered and pave the way for new therapeutic principles.

Acknowledgements. The data published was the M.Sc. thesis of the first author. This study was supported by a Grant from the Tabriz University of Medical Sciences.

\section{Conflict of interest statement}

The authors stated that they have no conflicts of interest regarding the publication of this article. 


\section{References}

1. Wang WC, Daselaar SM, Cabeza R. Episodic memory decline and healthy aging. Stein, J.(ed.), Reference module in neuroscience and biobehavioral psychology. 2017.

2. Holliday R. Aging is no longer an unsolved problem in biology. Annals of the New York Academy of Sciences 2006; 1067: 1-9.

3. Rattan SI, Clark BF. Understanding and modulating ageing. IUBMB life 2005; 57: 297-304.

4. Vina J, Borras C, Miquel J. Theories of ageing. IUBMB life 2007; 59: 249-54.

5. Yonei Y, Takabe W. Aging assessment by anti-aging medical checkup. Proceedings 2015; 42: 459-64.

6. Churchward Venne TA, Breen L, Phillips SM. Alterations in human muscle protein metabolism with aging: protein and exercise as countermeasures to offset sarcopenia. Biofactors 2014; 40: 199-205.

7. Distefano G, Goodpaster BH. Effects of Exercise and Aging on Skeletal Muscle. Cold Spring Harbor Perspectives in Medicine 2017; 21: a029785.

8. Francis P, Lyons M, Piasecki M, Mc Phee J, Hind K, Jakeman P. Measurement of muscle health in aging. Biogerontology 2017; 4: 1.

9. Moro T, Ebert SM, Adams CM, Rasmussen BB. Amino acid sensing in skeletal muscle. Trends in Endocrinology \& Metabolism 2016; 27: 796-806.

10. Wolfe RR. Regulation of muscle protein by amino acids. The Journal of Nutrition 2002; 132: 3219S-24S.

11. Shimbo K, Yahashi A, Hirayama K, Nakazawa M, Miyano $\mathrm{H}$. Multifunctional and highly sensitive precolumn reagents for amino acids in liquid chromatography/tandem mass spectrometry. Analytical Chemistry 2009; 81: 5172-9.

12. Rennie MJ, Bohé J, Wolfe RR. Latency, duration and dose response relationships of amino acid effects on human muscle protein synthesis. The Journal of Nutrition 2002; 132: 3225S-3227S

13. Semba RD, Nicklett EJ, Ferrucci L. Does accumulation of advanced glycation end products contribute to the aging phenotype? Journals of Gerontology Series A: Biomedical Sciences and Medical Sciences 2010; 65: 96375.

14. Saremi A, Howell S, Schwenke DC, Bahn G, Beisswenger PJ, Reaven PD. Advanced Glycation End Products, Oxidation Products, and the Extent of Atherosclerosis During the VA Diabetes Trial and Follow-up Study. Diabetes Care 2017; 40: 591-8.

15. Ziegler-Heitbrock L. The CD14+ CD16+ blood monocytes: their role in infection and inflammation. Journal of Leukocyte Biology 2007; 81: 584-92.

16. Alizadeh $M$, Kheirouri S. Curcumin against advanced glycation end products (AGEs) and AGEs-induced detrimental agents. Critical reviews in food science and nutrition 2017; 27: 1-9.

17. Kuhla A, Ludwig SC, Kuhla B, Münch G, Vollmar B. Advanced glycation end products are mitogenic signals and trigger cell cycle reentry of neurons in Alzheimer's disease brain. Neurobiology of Aging 2015; 36: 75361.

18. Ulrich P, Cerami A. Protein glycation, diabetes, and aging. Recent progress in hormone research 2001; 56: 1-22.

19. Exner M, Alt E, Hermann M, Hofbauer R, Kapiotis S, Quehenberger $P$, et al. p Hydroxyphenylacetaldehyde, the major product of tyrosine oxidation by the activated myeloperoxidase system can act as an antioxidant in LDL. FEBS letters 2001; 490: 28-31.

20. Guerra BA, Bolin AP, Morandi AC, Otton R. Glycolaldehyde impairs neutrophil biochemical parameters by an oxidative and calcium-dependent mechanism-Protective role of antioxidants astaxanthin and vitamin $\mathrm{C}$. Diabetes research and clinical practice 2012; 98: 10818.

21. Tahboub YR, Fares MM. A predictive kinetic model for inhibitory effect of nitrite on myeloperoxidase catalytic activity towards oxidation of chloride. Journal of Biophysical Chemistry 2011; 2: 202.

22. Iyer UM, Mani UV. Studies on the effect of curry leaves supplementation (Murraya koenigi) on lipid profile, glycated proteins and amino acids in non-insulin-dependent diabetic patients. Plant Foods for Human Nutrition (Formerly Qualitas Plantarum) 1990; 40: 275-82.

23. Sheedfar F, Biase SD, Koonen D, Vinciguerra M. Liver diseases and aging: friends or foes? Aging Cell 2013; 12: 950-4.

24. Yamamoto H, Kondo K, Tanaka T, Muramatsu T, Yoshida H, Imaizumi A, Nagao K, Noguchi Y, Miyano H. Reference intervals for plasma-free amino acid in a Japanese population. Annals of Clinical Biochemistry 2016; 53: 357-64.

25. De Alvaro C, Teruel T, Hernandez R, Lorenzo M. Tumor necrosis factor $\alpha$ produces insulin resistance in skeletal muscle by activation of inhibitor B kinase in a p38 MAPK-dependent manner. Journal of Biological Chemistry 2004; 279: 17070-8.

26. Lawton KA, Berger A, Mitchell M, Milgram KE, Evans AM, Guo L, et al. Analysis of the adult human plasma metabolome. Future Medicine 2008; 1: 383-97.

27. Menni C, Kastenmüller G, Petersen AK, Bell JT, Psatha $M$, Tsai PC, et al. Metabolomic markers reveal novel pathways of ageing and early development in human populations. International Journal of Epidemiology 2013; 42: 1111-19.

28. Yuksel M, Ates I, Kaplan M, Arikan FM, Ozin OY, Kilic YMZ, Topcuoglu C, Kayacetin E. Is oxidative stress associated with activation and pathogenesis of inflammatory bowel disease? J Med Biochem 2017; 36: 341-8.

29. Newsholme P, Abdulkader F, Rebelato E, Romanatto T, Pinheiro $\mathrm{CH}$, Vitzel KF, et al. Amino acids and diabetes: implications for endocrine, metabolic and immune function. Frontiers in bioscience (Landmark edition) 2011; 16: 315-39.

30. Slowick-Zylka D, Safranow K, Dziedziejko V, Dutkiewicz G, Ciechanowski K, Chlubek D. The influence of gender, 
weight, height and BMI on pentosidine concentrations in plasma of hemodialyzed patients. Journal of Nephrology 2006; 19: 65-9.

31. Vos PA, Mastbergen SC, Huisman AM, de Boer TN, DeGroot J, Polak AA, et al. In end stage osteoarthritis, cartilage tissue pentosidine levels are inversely related to parameters of cartilage damage. Osteoarthritis and Cartilage 2012; 20: 233-40.

32. Vos PA, Welsing PM, Huisman AM, Oostveen JC, Reijman M, Damen J, et al. Skin pentosidine in very early hip/knee osteoarthritis (CHECK) is not a strong independent predictor of radiographic progression over 5 years follow-up. Osteoarthritis and Cartilage 2013; 21 : 823-30.

33. Van Deemter M, Ponsioen TL, Bank RA, Snabel JM, Van der Worp RJ, Hooymans JM, et al. Pentosidine accumulates in the aging vitreous body: a gender effect. Experimental Eye Research 2009; 88: 1043-50.

34. Kandarakis SA, Piperi C, Topouzis F, Papavassiliou AG. Emerging role of advanced glycation-end products (AGEs) in the pathobiology of eye diseases. Progress in Retinal and Eye Research 2014; 42: 85-102.

35. Odetti P, Rossi S, Monacelli F, Poggi A, Cirnigliaro M, Federici $M$, et al. Advanced glycation end products and bone loss during aging. Annals of the New York Academy of Sciences 2005; 1043: 710-17.

36. Vaculík J, Braun M, Dungl P, Pavelka K, Stepan JJ. Serum and bone pentosidine in patients with low impact hip fractures and in patients with advanced osteoarthritis. BMC musculoskeletal disorders 2016; 17: 308.

37. Haus JM, Carrithers JA, Trappe SW, Trappe TA. Collagen, cross-linking, and advanced glycation end products in aging human skeletal muscle. Journal of Applied Physiology 2007; 103: 2068-76.

38. Takahashi M, Oikawa M, Nagano A. Effect of age and menopause on serum concentrations of pentosidine, an advanced glycation end product. The Journals of Gerontology Series A: Biological Sciences and Medical Sciences 2000; 55: M137-140.

39. Rattiste K, Klandorf H, Urvik J, Sepp T, Asghar M, Hasselquist $D$, et al. Skin pentosidine and telomere length do not covary with age in a long-lived seabird. Biogerontology 2015; 16: 435-41.

40. Hein G, Wiegand R, Lehmann G, Stein G, Franke S. Advanced glycation end-products pentosidine and $\mathrm{N}$ carboxymethyllysine are elevated in serum of patients with osteoporosis. Rheumatology 2003; 42: 1242-6.

41. Knecht KJ, Dunn JA, McFarland KF, McCance DR, Lyons TJ, Thorpe SR, et al. Effect of diabetes and aging on carboxymethyllysine levels in human urine. Diabetes 1991; 40: 190-6.

42. Tantalaki E, Piperi C, Livadas S, Kollias A, Adamopoulos C, Koulouri A, et al. Impact of dietary modification of advanced glycation end products (AGEs) on the hormonal and metabolic profile of women with polycystic ovary syndrome (PCOS). Hormones (Athens) 2014; 13: 65-73.

Received: November 22, 2017

Accepted: January 2, 2018 